\title{
A Turning Point in University Education: Impact on Quality Nursing Education
}

Jacinthe I. Pepin

Université de Montréal, jacinthe.pepin@umontreal.ca

Florence Myrick

amyrick@ualberta.ca

Follow this and additional works at: https://qane-afi.casn.ca/journal

Part of the Higher Education Commons

\section{Recommended Citation}

Pepin, Jacinthe I. and Myrick, Florence (2020) "A Turning Point in University Education: Impact on Quality Nursing Education," Quality Advancement in Nursing Education - Avancées en formation infirmière: Vol. 6: Iss. 3, Article 1. DOI: https://doi.org/10.17483/2368-6669.1273

This Editorial is brought to you for free and open access by Quality Advancement in Nursing Education - Avancées en formation infirmière. It has been accepted for inclusion in Quality Advancement in Nursing Education - Avancées en formation infirmière by an authorized editor of Quality Advancement in Nursing Education - Avancées en formation infirmière. 


\section{A turning point in university education: Impact on quality nursing education}

As we continue to experience unprecedented times, students, teachers, and academic administrators are rethinking the essentials of what needs to be learned to practice nursing, and more especially how such learning can be appropriately and efficiently provided, not only for the immediate situation but also for the long term. As educators, are we actively rethinking the core of our undergraduate and graduate nursing courses and programs? Could it be that the movement created by having to quickly turn around in response to the immediate induces a shift in our perspective of what is essential or even what is the profile of nursing graduates?

From the beginning of 2020, universities have found themselves at a crossroads affirming anew the pertinence of their mandate in communities. Through knowledge development and dissemination, university education aims at participating in sustainable future societies (Weber \& van der Swaan, 2020). What then would be the nursing contribution to such societies as a professional discipline, taking into account the current context and the necessary innovations? According to Myrick, Kelloway \& Arnold (2020, p. 5), "the post-COVID era will continue to require a vision of innovation. Indeed, crisis is a strong driver of creativity." So then, what does this mean for knowledge development and for curricular challenges? In a practice profession such as nursing, a major aspect of our educational preparation is the clinical experience. Indeed, the COVID-19 pandemic has generated a widespread disruption with regard to clinical placements not only for nursing students but also for those in other health care professions. Unlike the theoretical component of our educational programs, these experiences cannot be as easily replaced with distanced learning (Jackman, Konkin, Yonge, Myrick, \& Cockell, 2020). The challenge to provide relevant clinical experiences has generated an increased use of simulation and virtual reality. Invariably, we must address the question then, how can we innovatively provide clinical experiences without jeopardizing the safety of the student or the patient, while preparing the future generation of nurses to contribute to sustainable societies? This question is key to the educational process in particular and the nursing profession in general. While our immediate reactions may be to add content such as infectious and pandemic diseases in curricula, and to use technology as a replacement, such a response is not the only answer. Reminding ourselves of the interdependence of the clinical and academic milieus calls for a concerted effort to quality nursing education, focused on clinical innovations such as those that have been recently created and the ones currently in contemplation, since necessity is indeed the mother of invention.

Jacinthe Pepin and Florence Myrick

\section{Un tournant décisif dans l'enseignement universitaire : l’impact sur la qualité de la formation infirmière}

Alors que nous continuons de vivre une période sans précédent, les étudiantes, enseignantes et gestionnaires académiques sont en train de repenser les éléments fondamentaux de la formation pour les pratiques infirmières, et tout particulièrement comment cet enseignement peut être donné de façon plus adaptée et efficace, non seulement dans la situation actuelle mais aussi à long terme. En tant que formatrices, sommes-nous en train de repenser activement les savoirs essentiels de nos cours et nos programmes de sciences infirmières de premier cycle et des cycles supérieurs? Se pourrait-il que la dynamique engendrée par les 
décisions rapides qui ont dues être prises pour faire face à la situation ait provoqué un changement dans notre perspective de ce qui est essentiel ou de ce qu'est le profil même des diplômées en sciences infirmières?

Depuis le début de l'année 2020, les universités se sont retrouvées à la croisée des chemins en confirmant une fois de plus leur mission dans les communautés. Par le développement et la diffusion des connaissances, la formation universitaire a pour but de participer à créer des sociétés futures durables. (Weber et van der Swaan, 2020). Quelle serait alors la contribution des sciences infirmières dans de telles sociétés, en tant que discipline professionnelle, en prenant en compte le contexte actuel avec ses nécessaires innovations? D'après Myrick, Kelloway et Arnold (2020, p. 5), « [Traduction] ... L'ère post-Covid va continuer d'exiger une vision novatrice. Dans les faits, les crises sont de forts vecteurs de créativité. » Mais alors, que cela signifie-t-il pour le développement des connaissances et la transformation des programmes d'études? Dans une profession de pratique, telle que les sciences infirmières, une des composantes essentielles de la formation est l'expérience en milieu clinique. Dans les faits, la pandémie de la Covid-19 a engendré une perturbation généralisée en ce qui concerne les stages en milieu clinique, pas seulement pour les étudiantes en sciences infirmières mais également pour celles de tous les autres professionnels de la santé. Il n'est pas aussi évident de pouvoir remplacer ces stages par un enseignement à distance (Jackman, Konkin, Yonge, Myrick et Cockell, 2020). Le défi d'offrir des expériences cliniques valables à distance a engendré une utilisation croissante de pratiques en simulation et en réalité virtuelle. Du coup, il importe de poser la question : comment offrir des expériences cliniques novatrices sans compromettre la sécurité de nos étudiantes ou celle des patients - tout en préparant la future génération d'infirmières afin de contribuer à des sociétés durables? Cette question est la clé du processus éducatif en particulier et de la profession infirmière en général. Alors que la première réaction serait probablement d'ajouter du contenu sur les maladies infectieuses et les pandémies au programme, et d'utiliser la technologie en remplacement d'expériences en milieux de pratique, une telle réponse n'est pas suffisante. Se rappeler de l'interdépendance des milieux cliniques et académiques peut mener à un effort concerté pour une formation en sciences infirmières de qualité orientée vers des innovations cliniques, comme celles récemment inventées et celles encore en réflexion, puisque de la nécessité naît l'invention.

Jacinthe Pepin et Florence Myrick

\section{References / Références}

Jackman, D., Konkin, J., Yonge, O., Myrick, F., \& Cockell, J. (2020). Crisis and continuity: Rural health care students respond to the COVID-19 outbreak. Nursing Education in Practice, 48, 6. https://doi.org/10.1016/j.nepr.2020.102892

Myrick, K., Kelloway, E. K., \& Arnold, K. A. (2020). 6 ways universities are being put to the test by coronavirus. The Conversation. https://theconversation.com/6-ways-universitiesare-being-put-to-the-test-by-coronavirus-142222 
Weber, L. E., \& van der Zwaan, B. (Eds.) (2020). The University at the Crossroads to a Sustainable Future (Vol. 12). Association Glion Colloquium. https://glion.org/theuniversity-at-the-crossroads-to-a-sustainable-future-2/ 